\title{
Korelasi Antara Ergonomi Lingkungan dan Job Safety Analysis (JSA) Dengan Mechanical Integrity Program Pada PT. PAL Indonesia (Persero)
}

\author{
Zufan Ninggir Wicaksono ${ }^{1}$, Solichin ${ }^{2}$, Djoko Kustono ${ }^{3}$ \\ ${ }^{1,2,3}$ Program Studi S1 Pendidikan Teknik Mesin Jurusan Teknik Mesin \\ 1,2,3 Fakultas Teknik Universitas Negeri Malang \\ 1,2,3 Jalan Semarang No. 5, Malang 65145 \\ E-mail: zufanninggir.tpm3@gmail.com
}

\begin{abstract}
Abstrak; Penelitian ini bertujuan untuk mengetahui korelasi antara ergonomi lingkungan dan job safety analysis dengan mechanical integrity pada PT. PAL Indonesia (Persero). Data analisis penelitian menunjukkan bahwa (1) pemahaman ergonomi lingkungan mempunyai nilai kriteria 12 item sangat baik dan 3 item baik (2) penerapan job safety analysis mempunyai nilai kriteria 20 item sangat baik (3) penerapan mechanical integrity mempunyai nilai kriteria 20 item sangat baik dan 1 item baik (4) korelasi antara ergonomi lingkungan dengan mechanical integrity mempunyai nilai Thitung $>$ Ttabel $(7,3401>2,004)(5)$ korelasi antara job safety analysis dengan mechanical integrity mempunyai nilai Thitung > Ttabel $(14,8745>2,004)(6)$ korelasi antara ergonomi lingkungan dan job safety analysis dengan mechanical integrity mempunyai nilai Fhitung $>$ Ftabel $(109,216>3,1751)$.
\end{abstract}

Kata kunci: ergonomi lingkungan, job safety analysis, mechanical integrity

\begin{abstract}
This study aims to determine the relationship between environmental ergonomics and job safety analysis with mechanical integrity at PT. PAL Indonesia (Persero). Data from research analysis shows that (1) understanding environmental ergonomics has a value of 12 criteria item is very good and nice item 3 (2) the application of job safety analysis has a value of 20 items very good criteria (3) the application of the mechanical integrity has a value of 20 criteria item 1 item is very good and good (4) relationship between environmental ergonomics with mechanical integrity has a value of Tcount > Ttable $(7.3401>2.004)(5)$ the relationship between job safety analysis with mechanical integrity has a value of Tcount > Ttable $(14.8745>2.004)(6)$ the relationship between the environmental ergonomics and job safety analysis with mechanical integrity has a value of Fcount $>$ Ftable $(109.216>3.1751)$.
\end{abstract}

Keywords: environmental ergonomics, job safety analysis, mechanical integrity.

\section{PENDAHULUAN}

Perilaku manusia di dalam perusahaan pasti berkorelasi dengan keselamatan dan kecelakaan kerja, sebagai karyawan (pekerja) harus mendapat perhatian penting karena masih tingginya angka atau kejadian kecelakaan kerja. Menurut Hamalainen et al., (2017) perkiraan terbaru yang dikeluarkan oleh International Labour Organization (ILO), 2,78 juta pekerja meninggal setiap tahun karena kecelakaan kerja dan penyakit akibat kerja. sekitar 2,4 juta (86,3 persen) dari kematian ini dikarenakan penyakit akibat kerja, sementara lebih dari 380.000 (13,7 persen) dikarenakan kecelakaan kerja. Selain itu, data dari angka kecelakaan kerja terus menunjukkan tren meningkat. Badan Penyelenggara Jaminan Sosial (BPJS) Ketenagakerjaan mencatat, pada tahun 2017 angka kecelakaan kerja yang dilaporkan mencapai 123.041 kasus, sementara sepanjang 2018 mencapai 173.105 kasus dengan klaim Jaminan Kecelakaan Kerja (JKK) sebesar Rp 1,2 triliun. dan jumlah tersebut juga berasal dari berbagai industri termasuk juga industri manufaktur juga.

Kondisi lingkungan kerja tentunya memegang peranan penting terhadap baik buruknya kualitas hasil kinerja karyawan. Bila lingkungan kerja cukup nyaman dan komunikasi di dalamnya berjalan lancar, maka kinerja yang dihasilkan pun tentu akan maksimal. Oleh karena itu Sedarmayanti (2011) mendefinisikan lingkungan kerja segala sesuatu yang ada di sekitar karyawan pada saat bekerja, baik yang berbentuk fisik ataupun non fisik, langsung atau tidak langsung, yang dapat mempengaruhi dirinya dan pekerjaanya saat bekerja. Pekerjaan yang menghasilkan produk bagus harus mempunyai perencanaan yang bagus juga, salah satunya adalah job safety analysis (JSA) tetapi dalam penerapannya sebagian pekerja masih menganggap JSA hanya sebagai lembaran kertas biasa yang berisi daftar pekerjaan, bahaya, dan cara pengendaliannya. Padahal dibalik itu, JSA adalah sebuah alat penting yang membantu pekerja dalam melakukan pekerjaan secara aman dan efisien. Menurut Jafari (2014) Job Safety Analysis adalah suatu studi yang sistematis suatu pekerjaan yang seharusnya untuk mengidentifikasi potensi bahaya, evaluasi bobot risiko, dan metode kontrol untuk mengatur risiko yang dikenali. Program Mechanical Integrity sering berfokus pada masalah integritas peralatan yang diperlukan untuk memastikan keselamatan dan melindungi lingkungan. Program keandalan juga berfokus pada masalah integritas peralatan yang diperlukan untuk memastikan kinerja bisnis (mengurangi waktu henti pada saat proses). Mechanical Integrity ini menerapkan kegiatan manajemen pemeliharaan dan tugas pemeliharaan proaktif untuk mendeteksi, mencegah, dan mengelola kegagalan peralatan sebelum mempengaruhi kinerja. Oleh karena itu, 
konsep dan proses yang digunakan untuk mengembangkan dan menerapkan adalah program ITPM (Inspection, Testing, and Preventive Maintenance). PT. PAL Indonesia adalah salah satu industri strategis yang memproduksi alat utama sistem pertahanan Indonesia khususnya untuk matra laut, kegiatan bisnis utama memproduksi kapal perang dan kapal niaga. PT. PAL Indonesia (Persero) juga memberikan jasa perbaikan dan jasa pemeliharaan kapal, serta rekayasa umum dengan spesifikasi tertentu berdasarkan pesanan. Hal ini karena bekerja di PT. PAL Indonesia termasuk pekerjaan yang rawan terjadinya kecelakaan, tercatat pada data yang dibuat oleh Divisi K3LH dan Fasum (Keselamatan dan Kesehatan Kerja serta Lingkungan Hidup dan Fasilitas Umum) selama 4 tahun mulai dari tahun 2015 sampai dengan tahun 2018 telah terjadi 141 kecelakaan, maka diperlukan penanganan cepat dan tepat untuk kecelakaan kerja pada karyawan (pekerja) tersebut. Berdasarkan hal diatas, penelitian ini dilakukan untuk mengetahui adanya korelasi antara ergonomi lingkungan dan job safety analysis (JSA) dengan Mechanical Integrity pada PT. PAL Indonesia (Persero). Oleh karena itu, penelitian ini diharapkan mengetahui korelasi variabel diatas sehingga dapat meminimalisir kecelakaan dan bahkan dapat menerapkan zero accident pada perusahaan.

\section{METODE}

Sebuah penelitian diperlukan metode tertentu yang akan memberikan dasar atas penelitian yang dilakukan dan memecahkan permasalahan yang dipersoalkan, sehingga hasil dari penelitian akan menjadi hasil yang relevan dan dapat dipertanggung jawabkan. Metode yang dipilih pada penelitian ini adalah menggunakan rancangan penelitian kuantitatif. Hal ini digunakan karena penelitian berdasarkan data-data dan teori-teori. Dalam penelitian kuantitatif, penelitian dilakukan pada suatu rangkaian yang berawal dari sejumlah teori, yang kemudian didedukasikan menjadi sebuah hipotesa dan asumsi-asumsi suatu kerangka pemikiran yang terjabarkan dalam sebuah model analisa yang terdiri dari variabel-variabel dan mengarah pada operasional konsep. Penelitian ini bersifat korelasional dengan tujuan untuk menentukan ada tidaknya korelasi ergonomi lingkungan $\left(\mathrm{X}_{1}\right)$ dan Job Safety Analysis $\left(\mathrm{X}_{2}\right)$ dengan Mechanical Integrity (Y). Jika ada korelasi, seberapa besar keterkaitan variabel bebas dengan variabel tetap yaitu ergonomi lingkungan $\left(\mathrm{X}_{1}\right)$ dan Job Safety Analysis $\left(\mathrm{X}_{2}\right)$ dengan Mechanical Integrity (Y). Prosedur pengumpulan data dalam penelitian ini ada 4 yaitu tahap persiapan, tahap pelaksanaan, tahap pengolahan data, dan tahap penulisan laporan

Analisis data dibutuhkan untuk menjawab rumusan masalah, tujuan penelitian, dan menguji hipotesis penelitian. Analisis deskriptif merupakan analisis statistik untuk menganalisis data dengan cara mendeskripsikan data yang telah terkumpul sebagaimana adanya tanpa membuat kesimpulan yang berlaku untuk umum atau generalisasi. Uji persyarat diperlukan guna mengetahui apakah analisis data untuk pengujian hipotesis dapat dilanjutkan atau tidak. Adapun uji yang dilakukan dalam penelitian ini ada 4 pengujian yaitu uji normalitas, uji linearitas, uji autokorelasi, dan uji multikolinieritas. Hasil pengujian dari uji prasyarat analisis menunjukkan bahwa setiap variabel penelitian telah memenuhi syarat untuk dilakukan pengujian statistik lebih lanjut yaitu pengujian hipotesis. Hipotesis merupakan sebuah jawaban sementara atas masalah yang telah dirumuskan, oleh karena itu jawaban semestara ini harus diuji kebenarannya secara empiris. Proses pengujian hipotesis untuk menjawab adanya korelasi antara variabel bebas dengan variabel terikat, baik secara sendiri-sendiri maupun secara bersama-sama dengan menggunakan Software SPSS 25 for windows.

\section{Data Responden}

\section{HASIL}

Data-data mengenai responden sangat penting untuk mengetahui karakteristik dari responden. Dalam penelitian yang menjadi responden adalah karyawan PT. PAL Indonesia (Persero) pada divisi Kapal Perang, divisi Kapal Niaga, dan Divisi Jaminan Kualitas. Jumlah keseluruhan responden dalam penelitian ini sebanyak 55 orang.

Tabel 1. Data Responden Berdasarkan Jenis Kelamin, $n=55$

\begin{tabular}{|c|c|c|}
\hline Kategori & Frekuensi & Persentase \\
\hline Laki-Laki & 55 & $100 \%$ \\
\hline Perempuan & 0 & $0 \%$ \\
\hline Total & 55 & $100 \%$ \\
\hline
\end{tabular}

Tabel 2. Data Responden Berdasarkan Pendidikan Terakhir, $\mathrm{n}=55$

\begin{tabular}{|c|c|c|}
\hline Kategori & Frekuensi & Persentase \\
\hline SMA/Sederajat & 44 & $80 \%$ \\
\hline D3 & 5 & $9,1 \%$ \\
\hline S1 & 6 & $10.9 \%$ \\
\hline Total & 55 & $100 \%$ \\
\hline
\end{tabular}


Tabel 3. Data Responden Berdasarkan Usia Karyawan, $n=55$

\begin{tabular}{|l|c|c|}
\hline \multicolumn{1}{|c|}{ Kategori } & Frekuensi & Persentase \\
\hline $19-30$ Tahun & 22 & $40 \%$ \\
\hline $31-40$ Tahun & 23 & $41,8 \%$ \\
\hline $41-50$ Tahun & 7 & $12,7 \%$ \\
\hline$>50$ Tahun & 3 & $5,5 \%$ \\
\hline & 55 & $100 \%$ \\
\hline
\end{tabular}

Tabel 4. Data Responden Berdasarkan Lama Bekerja, $\mathrm{n}=55$

\begin{tabular}{|l|c|c|}
\hline \multicolumn{1}{|c|}{ Kategori } & Frekuensi & Persentase \\
\hline $1-5$ Tahun & 25 & $45,4 \%$ \\
\hline $6-10$ Tahun & 18 & $32,7 \%$ \\
\hline $11-15$ Tahun & 3 & $5,5 \%$ \\
\hline$>15$ Tahun & 9 & $16,4 \%$ \\
\hline & 55 & $100 \%$ \\
\hline
\end{tabular}

Analisis statistik yang dilakukan untuk menganilisis data yang terkumpul dan dipergunakan untuk mengidentifikasi karakteristik responden dan tanggapan responden atas variabel penelitian.

Tabel 5. Hasil Deskripsi Variabel

\begin{tabular}{|l|c|c|c|c|c|}
\hline \multirow{2}{*}{ Variabel } & \multicolumn{4}{|c|}{ Kriteria Item Peryataan } & \multirow{2}{*}{ Nilai Mean } \\
\cline { 2 - 5 } & Sangat Baik & Baik & Cukup & Buruk & \\
\hline Ergonomi Lingkungan & 12 & 3 & 0 & 0 & 3,161 \\
\hline Job Safety Analysis & 20 & 0 & 0 & 0 & 3,263 \\
\hline Mechanical Integrity & 20 & 1 & 0 & 0 & 3,171 \\
\hline
\end{tabular}

Uji persyarat diperlukan guna mengetahui apakah analisis data untuk pengujian hipotesis dapat dilanjutkan atau tidak Sebelum dilakukan pengujian hipotesis, terlebih dahulu dilakukan pengujian untuk memenuhi persyaratan untuk memperoleh penaksiran yang terbaik.

Tabel 6. Hasil Uji Normalitas Kolmogorov-Smirnov

\begin{tabular}{|c|c|c|c|}
\hline & Asymp. Sig. (2-tailed) & Taraf Sig. & Keterangan \\
\hline Data Residu & 0,176 & 0,05 & Normal \\
\hline
\end{tabular}

Tabel 7. Hasil Uji Autokorelasi dengan Run Test

\begin{tabular}{|c|c|c|c|}
\hline & Asymp. Sig. (2-tailed) & Taraf Sig. & Keterangan \\
\hline Data Residu & 0,228 & 0,05 & tidak autokorelasi \\
\hline
\end{tabular}

Tabel 8. Hasil Uji Linearitas Varibel $\mathrm{X}_{1}$ dengan $\mathrm{Y}$

\begin{tabular}{|l|c|c|c|}
\hline \multicolumn{1}{|c|}{ Variabel } & $\begin{array}{c}\text { Deviation from } \\
\text { Linearity Sig. }\end{array}$ & Taraf Sig. & Keterangan \\
\hline $\begin{array}{l}\text { Ergonomi Lingkungan dengan } \\
\text { Mechanical Integrity }\end{array}$ & 0,591 & 0,05 & Data linier \\
\hline $\begin{array}{l}\text { Job Safety Analysis dengan } \\
\text { Mechanical Integrity }\end{array}$ & 0,091 & 0,05 & Data linier \\
\hline
\end{tabular}


97 JURNAL TEKNIK MESIN DAN PEMBELAJARAN, Volume 2, Nomor 1, Juni 2019, Halaman: 94- 101

Tabel 9. Hasil Uji Autokorelasi dengan Run Test

\begin{tabular}{|c|c|c|c|}
\hline & Asymp. Sig. (2-tailed) & Taraf Sig. & Keterangan \\
\hline Data Residu & 0,228 & 0,05 & $\begin{array}{c}\text { Data tidak mengalami } \\
\text { autokorelasi }\end{array}$ \\
\hline
\end{tabular}

Tabel 10. Hasil Uji Multikolinieritas

\begin{tabular}{|c|c|c|c|}
\hline Variabel & Nilai Tolerance & Maks. Tolerance & Keterangan \\
\hline $\begin{array}{l}\text { Ergonomi } \\
\text { Lingkungan }\end{array}$ & 0,421 & 1,000 & $\begin{array}{c}\text { Tidak ada masalah } \\
\text { multikolinieritas }\end{array}$ \\
\hline $\begin{array}{l}\text { Job Safety } \\
\text { Analysis }\end{array}$ & 0,421 & 1,000 & $\begin{array}{c}\text { Tidak ada masalah } \\
\text { multikolinieritas }\end{array}$ \\
\hline Variabel & Nilai VIF & Maksimal VIF & Keterangan \\
\hline $\begin{array}{l}\text { Ergonomi } \\
\text { Lingkungan }\end{array}$ & 2,377 & 10,000 & $\begin{array}{c}\text { Tidak ada masalah } \\
\text { multikolinieritas }\end{array}$ \\
\hline $\begin{array}{l}\text { Job Safety } \\
\text { Analysis }\end{array}$ & 2,377 & 10,000 & $\begin{array}{c}\text { Tidak ada masalah } \\
\text { multikolinieritas }\end{array}$ \\
\hline
\end{tabular}

Hasil pengujian dari uji prasyarat analisis menunjukkan bahwa setiap variabel penelitian telah memenuhi syarat untuk dilakukan pengujian statistik lebih lanjut yaitu pengujian hipotesis. Hipotesis merupakan sebuah jawaban sementara atas masalah yang telah dirumuskan, oleh karena itu jawaban semestara ini harus diuji kebenarannya secara empiris. Proses pengujian hipotesis untuk menjawab adanya korelasi antara variabel bebas dengan variabel terikat, baik secara sendiri-sendiri maupun secara bersama-sama dengan menggunakan Software SPSS 25 for windows.

Tabel 11. Hasil Uji Korelasi Pearson

\begin{tabular}{|l|c|c|l|}
\hline \multicolumn{1}{|c|}{ Variabel } & Nilai Sig. & Korelasi Pearson & Keterangan \\
\hline $\begin{array}{l}\text { Ergonomi Lingkungan dengan } \\
\text { Mechanical Integrity }\end{array}$ & 0,000 & 0,710 & $\begin{array}{l}\text { Mempunyai korelasi kuat } \\
\text { dan positif }\end{array}$ \\
\hline $\begin{array}{l}\text { Job Safety Analysis dengan } \\
\text { Mechanical Integrity }\end{array}$ & 0,000 & 0,898 & $\begin{array}{l}\text { Mempunyai korelasi } \\
\text { sangat kuat dan positif }\end{array}$ \\
\hline
\end{tabular}

Tabel 12. Hasil Uji Regresi Linier Berganda

\begin{tabular}{|l|c|c|c|l|}
\hline \multicolumn{1}{|c|}{ Variabel } & Sig. F Change & $\mathrm{R}$ & $R$ Square & \multicolumn{1}{|c|}{ Keterangan } \\
\hline $\begin{array}{l}\text { Ergonomi Lingkungan dan } \\
\text { Job Safety Analysis dengan } \\
\text { Mechanical Integrity }\end{array}$ & 0,000 & 0,899 & 0,808 & $\begin{array}{l}\text { Mempunyai } \\
\text { korelasi sangat } \\
\text { kuat dan positif }\end{array}$ \\
\hline
\end{tabular}

Berdasarkan hasil perhitungan dengan menggunakan bantuan software SPSS 25 for windows, korelasi antara ergonomi lingkungan dengan mechanical integrity diperoleh nilai koefisien korelasi sebesar $r_{x 1 y}=0,710$; kemudian dilanjutkan dengan uji statistik yaitu uji t untuk membuktikan apakah hipotesis alternatif diterima atau ditolak dengan cara membandingkan $t_{\text {hitung }}$ dengan $t_{\text {tabel }}$.

$$
t=\frac{r \sqrt{n-2}}{\sqrt{1-r^{2}}}
$$




$$
\begin{aligned}
& t=\frac{0,710 \sqrt{55-2}}{\sqrt{1-(0,710)^{2}}} \\
& t=\frac{5,1689}{0,7042}=7,3401
\end{aligned}
$$

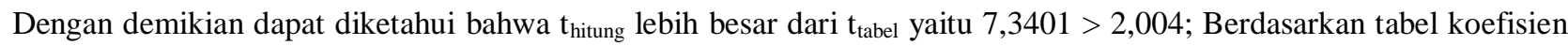
korelasi (r) dapat diinterpretasikan variabel ergonomi lingkungan $\left(\mathrm{X}_{1}\right)$ dengan variabel mechanical integrity (Y) terdapat korelasi yang kuat dan positif. Korelasi antara job safety analysis dengan mechanical integrity diperoleh nilai koefisien korelasi sebesar $r_{x 1 y}=0,899$; kemudian dilanjutkan dengan uji statistik yaitu uji $\mathrm{t}$ untuk membuktikan apakah hipotesis alternatif diterima atau ditolak dengan cara membandingkan $t_{\text {hitung }}$ dengan $t_{\text {tabel. }}$.)

$$
\begin{aligned}
& t=\frac{0,899 \sqrt{55-2}}{\sqrt{1-(0,899)^{2}}} \\
& t=\frac{6,5448}{0,44}=14,8745
\end{aligned}
$$

Dengan demikian dapat diketahui bahwa $t_{\text {hitung }}$ lebih besar dari $t_{\text {tabel }}$ yaitu 14,8745 > 2,004; Berdasarkan tabel koefisien korelasi (r) dapat diinterpretasikan variabel job safety analysis $\left(\mathrm{X}_{2}\right)$ dengan variabel mechanical integrity $(\mathrm{Y})$ terdapat korelasi yang sangat kuat dan positif. Uji korelasi ganda untuk mengetahui korelasi antara 2 variabel bebas dan 1 variabel terikat menggunakan rumus sebagai berikut:

$$
\begin{aligned}
& F_{0}=\frac{R^{2} / k}{\left(1-R^{2}\right) /(n-k-1)} \\
& F_{0}=\frac{0,899^{2} / 2}{\left(1-0,899^{2}\right) /(55-2-1)} \\
& F_{0}=\frac{0,4041}{0,0037}=109,216
\end{aligned}
$$

Hasil analisis pengujian hipotesis diatas menggunakan uji statistik koefisien korelasi ganda, dan diperoleh hasil $\mathrm{F}_{\text {hitung }}$ sebesar 109,216 dan nilai $F_{\text {tabel }}$ 3,1751. Dengan demikian dapat diketahui bahwa $F_{\text {hitung }}$ lebih besar dari $F_{\text {tabel }}$ kemudian diinterpretasikan bahwa $\mathrm{H}_{0}$ dalam penelitian ini ditolak dan $\mathrm{H}_{1}$ diterima. $\mathrm{H}_{1}$ berbunyi "ada korelasi antara ergonomi lingkungan dan job safety analysis dengan mechanical integrity pada PT. PAL Indonesia (Persero)”.

\section{PEMBAHASAN}

\section{Ergonomi Lingkungan}

Pemahaman lingkungan kerja di PT. PAL Indonesia (Persero) mencakup pemahaman lingkungan kerja fisik: (1) kebersihan mengindikasikan kriteria sangat baik; (2) penerangan mengindikasikan kriteria sangat baik; (3) Pertukaran udara mengindikasikan kriteria sangat baik; (4) Keamanan mengindikasikan kriteria sangat baik; (5) Peralatan dan atau perlengkapan kerja mengindikasikan kriteria sangat baik; (6) Kebisingan mengindikasikan kriteria sangat baik. Pemahaman lingkungan kerja non fisik mencerminkan suatu kondisi kerja yang menuntut untuk suasana kekeluargaan, komunikasi terhadap atasan (manager, kepala divisi, dll) dan sesama karyawan PT. PAL Indonesia (Persero). Manajer tidak mungkin menyelesaikan semua pekerjaan sendiri tanpa bantuan karyawan dan karyawan tidak mungkin menyelesaikan pekerjaan dengan baik tanpa komando yang jelas 
dari manajer. karyawan merasa senang apabila rekan kerjanya bisa diajak kerjasama, bila ada kesulitan oleh karyawan yang satunya, karyawan yang lain dapat saling membantu. Hal ini sama seperti yang dikemukakan Sedarmayanti (2011:26) yaitu korelasi kerja yang baik antara yang satu dengan yang lain dapat meningkatkan semangat kerja bagi pegawai, di mana mereka saling bekerja sama atau saling membantu dalam menyelesaikan suatu pekerjaan.

\section{Job Safety Analysis}

Penerapan job safety analysis pada karyawan PT. PAL Indonesia (Persero) mencakup 4 hal yaitu (1) memilih pekerjaan mengindikasikan kriteria sangat baik; (2) mengurai prosedur kerja mengindikasikan kriteria sangat baik; (3) identifikasi bahaya dan potensi kecelakaan mengindikasikan kriteria sangat baik; (4) pengendalian dan pengembangan solusi mengindikasikan kriteria sangat baik.

\section{Mechanical Integrity}

Program mechanical integrity berfokus pada proses Inspection, Testing, and Preventive Maintenance (ITPM), dimana ITPM tersebut melibatkan dua fase dalam pelaksanaannya yaitu perencanaan tugas-tugas ITPM serta pelaksanaan dan pemantauan ITPM. Deskripsi tentang penerapan mechanical integrity dengan pelaksanaan 2 fase tersebut pada karyawan PT. PAL Indonesia (Persero) yaitu memahami perencanaan tugas-tugas ITPM yang mencakup (1) memilih tugas-tugas ITPM mengindikasikan kriteria sangat baik; (2) mengembangkan kriteria pengambilan sampel mengindikasikan kriteria sangat baik, hal ini mempunyai fokus pada deteksi sebuah material atau peralatan yang akan menjadi titik uji untuk menilai kondisi tersebut, penentuan sampel untuk pengujian tidak boleh sembarangan harus ada dasarnya, seperti yang dikemukakan oleh American Petroleum Institute (2003) yaitu konsekuensi dari kerusakan, tingkat kerusakan yang diharapkan, adanya penurunan kerja, konfigurasi peralatan, dan potensi kerusakan mekanis yang tidak biasa; (3) pertimbangan perencanaan ITPM mengindikasikan kriteria sangat baik; (4) menentukan penjadwalan tugas ITPM mengindikasikan kriteria baik. Pelaksanaan dan pemantauan ITPM merupakan langkah lanjutan dari perencanaan tugas-tugas ITPM. Deskripsi tentang penerapan mechanical integrity fase pelaksanaan dan pemantauan ITPM yaitu (1) menentukan syarat penerimaan mengindikasikan kriteria sangat baik; (2) dokumentasi hasil tugas dan peralatan ITPM mengindikasikan kriteria sangat baik; (3) pelaksanaan dan eksekusi tugas ITPM mengindikasikan kriteria sangat baik; (4) manajemen hasil tugas ITPM mengindikasikan kriteria sangat baik; (5) manajemen jadwal tugas mengindikasikan kriteria sangat baik; (6) pemantauan program ITPM mengindikasikan kriteria sangat baik.

\section{Korelasi antara Ergonomi Lingkungan dengan Mechanical Integrity pada PT. PAL Indonesia (Persero)}

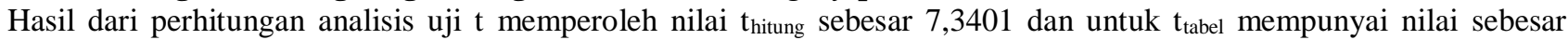
2,004. Hal tersebut bisa diambil sebuah keputusan dengan membandingkan thitung dengan $t_{\text {tabel }}$ yaitu 7,3401>2,004 pada taraf signifikansi sebesar $0,05(5 \%)$ dan jumlah sampel sebanyak 55 responden, sehingga dapat dinterpretasikan bahwa $\mathrm{H}_{1 \mathrm{a}}$ diterima mempunyai pengertian yaitu ada korelasi antara ergonomi lingkungan (X1) dengan mechanical integrity (Y). sedangkan besar korelasinya adalah 0,710. Berdasarkan hasil keluaran tersebut dapat disimpulkan bahwa jika semakin tinggi pemahaman ergonomi lingkungan, maka penerapan mechanical integrity akan semakin tinggi pula.

Pemahaman mengenai lingkungan kerja pada perusahaan sangat penting karena berdampak pada proses pengerjaan, alat pelindung diri yang digunakan, dan hasil produk dari karyawan. Apabila pemahaman ergonomi lingkungan karyawan pada perusahaan tinggi maka karyawan akan mengerti juga kondisi lingkungan kerja pada bengkelnya dan mampu menerapkan mechanical integrity dengan baik, karena program mechanical integrity yaitu ITPM memerlukan lingkungan kerja fisik yang memadai seperti penerangan yang tidak membuat silau indera penglihatan, suara bising yang mengganggu kesehatan telinga, peralatan kerja yang standar untuk digunakan, dan ventilasi yang cukup. Hal ini diperkuat oleh Imam Fadhilah Mukti, Listiani Nurul Huda, A. Rahim Matondang (2013) yaitu temperatur sangat mempengaruhi lingkungan kerja mengenai masalah panas di lantai produksi yang dapat menimbulkan paparan panas bagi para pekerja. Penyebabnya adalah kurangnya ventilasi dan kecepatan angin yang mengakibatkan panas yang terus berakumulasi di lantai produksi. Dan sesuai dengan Peraturan Menteri Kesehatan Republik Indonesia Nomor 70 Tahun 2016 Tentang Standar Dan Persyaratan Kesehatan Lingkungan Kerja Industri Pasal 1 yang berbunyi "Pengaturan standar dan persyaratan kesehatan lingkungan kerja industri bertujuan untuk: (a) mewujudkan kualitas lingkungan kerja industri yang sehat dalam rangka menciptakan pekerja yang sehat dan produktif; (b) mencegah timbulnya gangguan kesehatan, penyakit akibat kerja, dan kecelakaan kerja; dan (c) mencegah timbulnya pencemaran lingkungan akibat kegiatan industri”. Hal ini diperkuat oleh penelitian Rusdiansyah (2017) yaitu dari hasil perhitungan Uji F (simultan) menunjukan bahwa variabel Lingkungan Kerja fisik dan non fisik secara simultan berpengaruh signifikan terhadap kinerja karyawan Kantor Pada PT. PLN (Persero) Wilayah Kalimantan Timur dan Kalimantan Utara Sektor Pembangkit Mahakam di Samarinda.

\section{Korelasi antara Job Safety Analysis (JSA) dengan Mechanical Integrity pada PT. PAL Indonesia (Persero)}

Hasil dari perhitungan analisis uji $\mathrm{t}$ bisa diambil keputusan dengan membandingkan $t_{\text {hitung }}$ dengan $\mathrm{t}_{\text {tabel }}$ yaitu $14,8745>$ 2,004 sehingga dapat dinterpretasikan bahwa $\mathrm{H}_{1 \mathrm{~b}}$ diterima mempunyai pengertian yaitu ada korelasi antara variabel job safety analysis (X2) dengan variabel mechanical integrity $(\mathrm{Y})$. Hasil analisis untuk mengetahui seberapa besar korelasi antara variabel 
job safety analysis $(\mathrm{X} 2)$ dengan variabel mechanical integrity $(\mathrm{Y})$ yaitu $\mathrm{r}_{\text {hitung }}$ sebesar 0,898 . Hal ini juga bisa diambil sebuah keputusan dengan membandingkan $\mathrm{r}_{\text {hitung }}$ dengan $\mathrm{r}_{\text {tabel }}$ yaitu $0,898>0,2656$. Berdasarkan hasil keluaran tersebut dapat disimpulkan bahwa jika semakin tinggi penerapan job safety analysis, maka penerapan mechanical integrity akan semakin tinggi pula. Penerapan mengenai job safety analysis pada perusahaan sangat penting karena mampu memberikan dampak pada proses pengerjaan material dan juga menjamin karyawan tetap dalam keselamatan bekerja. Apabila penerapan job safety analysis pada perusahaan memiliki pengaruh yang tinggi maka karyawan akan memahami risiko dari pekerjaan tersebut dan bahaya yang dialaminya dan mampu menerapkan program mechanical integrity dengan lancar, karena mechanical integrity mempunyai fokus pada ITPM yang mempunyai potensi bahaya kecelakaan. Hal tersebut membuat job safety analysis menjadi solusi dalam mengendalikan bahaya karena mampu meminimalisir atau bahkan menghilangkan dari kecelakaan yang terjadi. Hal tersebut diperkuat oleh Mohsen Mohammadi Asl (2017) yaitu bahaya dapat dikendalikan dalam suatu pekerjaan dengan menggunakan metode job safety analysis sehingga bisa mengurangi biaya kecelakaan pada pekerja dan mesin. Hal ini didukung oleh penelitian Dewi Diniaty dan Zulfan Afendi (2015) yang mengemukakan bahwa hasil dari job safety analysis digunakan untuk melengkapi data lembar kerja yang sudah ada dalam identifikasi aspek dan dampak. Hal ini dimaksudkan agar tenaga kerja tersebut paham akan potensi bahaya yang timbul dari aktivitas pekerjaan dan cara pencegahannya. Dengan adanya kegiatan job safety analysis dapat mengurangi frekuensi bahaya di tempat kerja, sehingga kesadaran dari tenaga kerja untuk melakukan sesuatu pekerjaaan sesuai dengan WI (Work Instruction) dan SOP (Standart Operasional Prosedur) yang ada. Diperkuat lagi oleh penelitian Akhmad Syakhroni (2007) yang mengemukakan bahwa penerapan process safety management yang dipadukan dengan prosedur Job Safety Analysis dapat meminimalisir kecelakaan pada PT. Pertamina (Persero) UP VI Balongan. Penggunaan alat pelindung diri dan Safety Talk sebelum melaksanakan pekerjaan juga penting untuk menunjang tercapainya Zero Accident.

\section{Korelasi antara Ergonomi Lingkungan dan Job Safety Analysis (JSA) dengan Mechanical Integrity pada PT. PAL Indonesia (Persero)}

Hasil dari perhitungan analisis uji $\mathrm{F}$ bisa diambil sebuah keputusan dengan membandingkan $\mathrm{F}_{\text {hitung }}$ dengan $\mathrm{F}_{\text {tabel }}$ yaitu $109,216>3,1751$ sehingga dapat dinterpretasikan bahwa $\mathrm{H}_{\mathrm{a}}$ diterima mempunyai pengertian yaitu ada korelasi antara ergonomi lingkungan (X1) dan job safety analysis (X2) dengan variabel mechanical integrity (Y). Hasil analisis untuk seberapa besar korelasi antara ergonomi lingkungan (X1) dan job safety analysis (X2) dengan mechanical integrity (Y) yaitu $\mathrm{r}_{\text {hitung sebesar }}$ 0,898 . Berdasarkan hasil keluaran tersebut dapat disimpulkan bahwa jika semakin tinggi pemahaman ergonomi lingkungan dan penerapan job safety analysis, maka penerapan mechanical integrity akan semakin tinggi pula. Besarnya kontribusi ergonomi lingkungan dan job safety analysis dengan mechanical integrity dapat dilihat pada $R$ Square $\left(\mathrm{R}^{2}\right)$ yaitu $0,8082(80,82 \%)$, hal tersebut menyebabkan pemahaman ergonomi lingkungan dan penerapan job safety analysis di perusahaan PT. PAL Indonesia mempunyai nilai kontribusi sebesar 80,82\% pada mechanical integrity dan sisanya sebesar $19,18 \%$ ditentukan atau dipengaruhi oleh variabel lain yang tidak diteliti.

Fokus dari ergonomi lingkungan dan job safety analysis berjalan beriringan, dimana ergonomi lingkungan merupakan pemahaman yang dapat membuat karyawan mengerti kondisi lingkungan kerja sedangkan job safety analysis merupakan teknik yang berfokus pada pengendalian potensi dan bahaya kecelakaan di perusahaan. Hal tersebut didukung oleh penelitian $\mathrm{F}$. Walter Pinto (2008) yaitu struktur organisasi, deskripsi pekerjaan, alur kerja, peran dan tanggung jawab sangat penting untuk keberhasilan program keandalan mechanical integrity. Tiga elemen kunci dari praktek keandalan tersebut adalah inspeksi untuk manajemen, program peningkatan kehandalan yang terfokus, dan kegagalan dalam pelaporan dan penyelidikan. PT. PAL Indonesia merupakan perusahaan yang rawan kecelakaan dengan intensitas tinggi, bila manager atau karyawan tidak mengerti mengenai job safety analysis maka karyawan akan bekerja tidak sesuai prosedur kerja yang ada. Korelasi pada mechanical integrity adalah ergonomi lingkungan sebagai pendukung dalam menerapkan proses ITPM. Proses ITPM untuk inspeksi dan pengetesan memerlukan lingkungan kerja yang memadai karena penggunaan alat sensor yang sensitif, bila lingkungan kerja buruk pada perusahaan maka peralatan ITPM tidak akan melaksanakan proses pengerjaan dengan baik. Sedangkan untuk job safety analysis pada mechanical integrity berperan pada seluruh aspek ITPM. Sebuah kecelakaan tidak bisa diprediksi kapan, dimana, dan bagaimana bisa terjadi, karyawan dan manager hanya bisa mengidentifikasi untuk meminimalisir ataupun menghilangkan potensi kecelakaan. proses ITPM rawan dengan terjadinya kecelakaan bila tidak sesuai standar operasional prosedur (SOP), maka karyawan harus memahami penerapan job safety analysis untuk membuat penerapan dari mechanial integrity menjadi efektif dan efisien. Seperti yang diungkapkan oleh Paolo A. Bragatto, Paolo Pittiglio, dan Silvia Ansaldi (2009) yaitu korelasi yang kuat antara sistem manajemen keamanan dan Mechanical Integrity harus didorong oleh atasan. Inspeksi dilakukan di bawah sistem manajemen keselamatan, terutama kebijakan keamanan, prosedur, personel, pelatihan dan perencanaan darurat.

\section{SIMPULAN}

Dari hasil analisis data, pengujian hipotesis dan pembahasan yang telah dilakukan dapat diperoleh kesimpulan sebagai berikut: 1) Karyawan pada divisi kapal perang, divisi kapal niaga, dan divisi jaminan kualitas PT. PAL Indonesia (Persero) memiliki pemahaman ergonomi lingkungan yang sangat baik. 2) Karyawan pada divisi kapal perang, divisi kapal niaga, dan 
divisi jaminan kualitas PT. PAL Indonesia (Persero) telah menerapkan job safety analysis yang sangat baik. 3) Karyawan pada divisi kapal perang, divisi kapal niaga, dan divisi jaminan kualitas PT. PAL Indonesia (Persero) telah menerapkan mechanical integrity yang sangat baik. 4) Ergonomi lingkungan berkorelasi dengan mechanical integrity. Dari uji analisis diperoleh nilai $t_{\text {hitung }}>\mathrm{t}_{\text {tabel }}(7,3401>2,004)$ dan nilai korelasi pearson sebesar 0,710. Dapat diinterpretasikan ergonomi lingkungan memiliki korelasi positif dan kuat dengan mechanical integrity pada PT. PAL Indonesia (Persero). 5) Job safety analysis berkorelasi dengan mechanical integrity. Dari uji analisis diperoleh nilai $t_{\text {hitung }}>t_{\text {tabel }}(14,8745>2,004)$ dan nilai korelasi pearson sebesar 0,898. Dapat diinterpretasikan job safety analysis memiliki korelasi positif dan sangat kuat dengan mechanical integrity pada PT. PAL Indonesia (Persero). 6) Ergonomi lingkungan dan Job safety analysis berkorelasi dengan Mechanical integrity. Analisis diperoleh nilai $F_{\text {hitung }}>F_{\text {tabel }}(109,216>3,1751)$ dan nilai korelasi regresi linier berganda sebesar 0,898 sehingga memiliki korelasi positif dan sangat kuat dengan mechanical integrity pada PT. PAL Indonesia (Persero). Kontribusi ergonomi lingkungan dan job safety analysis dengan mechanical integrity sebesar 80,82\%.

\section{DAFTAR PUSTAKA}

American Petroleum Institute. 2003. Piping Inspection Code: inspection, Repair, Alteration, and Rerating of In-Service Piping. Washington, DC: API 570

Asl, Mohsen Mohammadi. 2017. Job Safety Analysis (Human \& Equipment). Universal Journal of Management, 5(7): 355363

Bragatto, Paolo A., Paolo Pittiglio, dan Silvia Ansaldi. 2009. The Management Of Mechanical Integrity Inspections At SmallSized “Seveso”' Facilities. Reliability Engineering and System Safety 94 (2009) 412- 417 journal homepage: www.elsevier.com/locate/ress

Diniaty, Dewi dan Zulfan Afendi. 2015. Usulan Perbaikan Keselamatan Kerja untuk Meminimumkan Kecelakaan Kerja dengan Pendekatan Job Safety Analysis (JSA) pada Area Lantai Produksi di PT. Alam Permata Riau. Jurnal Sains, Teknologi dan Industri, Vol. 13, No.1, Desember 2015, pp.91-98 ISSN 1693-2390

Hämäläinen, P.; Takala, J.; \& Boon Kiat, T. (2017). Perkiraan Global Kecelakaan Kerja dan Penyakit yang Berhubungan dengan Kerja 2017. Kongres Dunia XXI tentang Keselamatan dan Kesehatan di Tempat Kerja. Singapura: Lembaga Keselamatan dan Kesehatan Kerja.

Jafari, Hassan. 2014. Evaluation of Occupational Hazards of Quay Side Crane Operator Using Job Safety Analysis. American Journal of Marine Science, 2, 2, 33-37. Dari: pubs.sciepub.com/marine/2/2/1/

Mukti, Imam Fadhilah, Listiani Nurul Huda, A. Rahim Matondang. 2013. Desain Perbaikan Lingkungan Kerja Guna Mereduksi Paparan Panas Kerja Operator Di PT. XY. e-Jurnal Teknik Industri FT USU Vol 1, No.1, Januari 2013 pp. 28-34

Pinto, F. Walter. 2008. Mechanical Integrity - Stationary Equipment Reliability. Process Safety Progress (Vol.27, No.2) 105111 June 2008

Peraturan Menteri Kesehatan Republik Indonesia Nomor 70 Tahun 2016 Tentang Standar Dan Persyaratan Kesehatan Lingkungan Kerja Industri

Sedarmayanti. 2011. Manajemen Sumber Daya Manusia. Reformasi Birokrasi dan Manajemen Pegawai Negeri Sipil, Cetakan Kelima, PT Refika Aditama, Bandung.

Sugiyono. 2011. Metode Penelitian Kuantitatif, Kualitatif dan R\&D. Bandung: Afabeta

Syakhroni, Akhmad. 2007. Penerapan Manajemen Keselamatan Proses (Cara Kerja Aman) Dengan Pendekatan Job Safety Analysis (JSA) Studi Kasus di Unit ITP PT. Pertamina (Persero) UP - VI Balongan. Transistor. Vol. 7. No. 1, Juli 2007: 55-64. 